\title{
Spatio-Temporal Pattern of Gender Disparity in Literacy: A Block Level Study of Mizoram
}

\author{
Janet Laltlansangi", C.Laldingliana ${ }^{* *}$, Jacinta Vanlalrinzuali** \\ * Assistant Professor, Department of Geography, Government Kolasib College, Mizoram \\ ** Assistant Professor, Department of Geography, Lunglei Government College, Mizoram \\ ** Assistant Professor, Department of Geography, Lunglei Government College, Mizoram
}

DOI: 10.29322/IJSRP.11.10.2021.p11864

http://dx.doi.org/10.29322/IJSRP.11.10.2021.p11864

\begin{abstract}
The present study seeks to determine the space time investigation of gender disparities in literacy in Mizoram. Although the effective literacy rate is quite high (91.33\% in 2011 Census), the geographic pattern of literacy rate is relatively uneven over different parts of the State. At the same time, there exists a significant gap in literacy rates between male and female, and between rural and urban area. The temporal analysis of literacy reveals that the gap in literacy rate is slowly narrowing down with time. However, due to various socio economic and cultural factors such as poverty, ignorance, patriarchal system, social custom, conservative attitude of family etc incidence of gender disparity can still be found in many parts of the State.
\end{abstract}

Index Terms- Literacy rate, Spatio-temporal pattern, Gender gap, Disparity, Rural Development Block

\section{Introduction}

The concept of literacy varies from space to space and from time to time. While some country defines it as the ability to communicate orally, some country defines it on the basis of length of schooling. In India, the Census of India defines literacy as 'the ability to read and write with understanding in any language'. Literacy is an important qualitative aspect of human resource because it is considered as one of the key indicator of socio-economic transformation and cultural advancement of an area. The foundation for development of economic skill is provided by literacy and it plays an important role in softening the resistance to change. Thus, the level of literacy reflects the quality of present and potential workforce to a great extent. Literacy is both the cause and result of development (Mohapatra, 1993). It is therefore now regarded as the catalysts of socio-economic transformation. In this context, emphasis must be given on the level of female literacy rate and the subsequent gender gap between male and female. As a member of a biologically weaker section of the society, especially in a patriarchal and patrilineal society, women are subjected to differential treatment than their male counterparts in family as well as in society. Underachievement of women in general and literacy in particular is a cause of great concern because it has the potential to hampered socio-economic development. Real economic growth cannot be achieved if certain section of the society remains neglected. The pattern of gender disparity in literacy varies through time and from region to region. While the gender gap in literacy is slowly narrowing down as society made progresses, there are still regions where more effort is required in this context to reduce the gap. Therefore, it is imperative to present a careful analysis of gender disparity in literacy in order to show the spatial pattern of variation so that necessary measures can be implemented. 


\section{STUDY AREA}

The State of Mizoram is located between $21^{\circ} 56^{\prime} \mathrm{N}-24^{\circ} 31^{\prime} \mathrm{N}$ latitudes and $92^{\circ} 16^{\prime} \mathrm{E}-93^{\circ} 26^{\prime} \mathrm{E}$ longitudes. With a geographical area of $21,087 \mathrm{sq} \mathrm{km}$, it is the $5^{\text {th }}$ smallest state in India in terms of area. It is bounded on the west by Bangladesh and Myanmar on the east and south, thus sharing a total of $722 \mathrm{~km}$ international boundaries with these two countries. It also share domestic border with Tripura, Assam and Manipur. As per 2011 Census, the total population of Mizoram was 10, 91,014, characterized by highly literate, highly urbanized but predominantly agrarian society, and mainly composed of tribal people of mongoloid descendants.

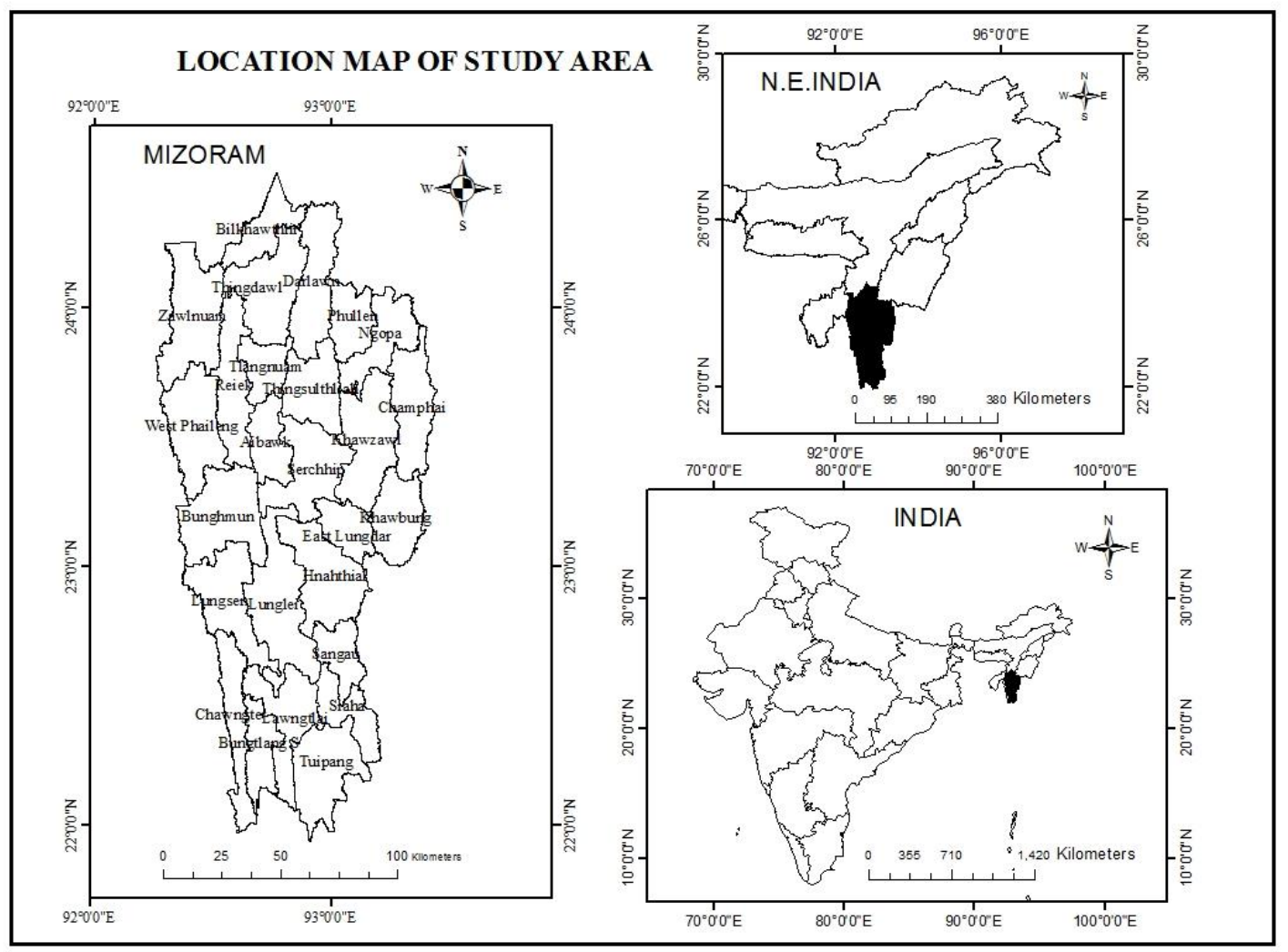

Fig.1: Location Map of the Study Area

III. METHODOLOGY

The study has been carried out solely based on secondary data collected from Primary Census Abstract of Mizoram published by Census of India for the last three decadal censuses i.e. 1991-2011. The unit of analysis is Rural Development Block. Due to frequent district and block boundary modification during the study period, suitable adjustment has been made to make the data comparable. The tabulated data was then processed and analysed with the help of statistical techniques and relevant GIS software. Spatial pattern of disparity for each census year is represented in a map.

For calculating the rate of crude literacy, the following formula is used:

$$
\text { Crude Literacy Rate } \quad=\frac{\text { Total literate population X } 100}{\text { Total population }}
$$

For determining level of disparities between male-female literacy Sopher's Disparity Index is used.

Disparity Index $=\log (\mathrm{X} 2 / \mathrm{X} 1)+\underline{\log (\mathrm{Q}-\mathrm{X} 1)}$

Where,

$$
\log (\mathrm{Q}-\mathrm{X} 2)
$$

$$
\begin{aligned}
& \mathrm{Q}=100 \\
& \mathrm{X} 1=\text { Male literacy rate } \\
& \mathrm{X} 2=\text { Female literacy rate }
\end{aligned}
$$


In Sopher's method, the greater value of DI meant that there is higher extent of disparity between the two variables and vice versa. If there is no disparity between the two variables i.e. in case of perfect equality, the DI value will be zero. The disparity indices are calculated separately for rural and urban literacy.

Table.1- Block Wise Disparity in Literacy 1991-2011

\begin{tabular}{|c|c|c|c|c|c|c|c|c|c|}
\hline \multirow{2}{*}{$\begin{array}{l}\text { Name of } \\
\text { Blocks }\end{array}$} & \multicolumn{3}{|c|}{ Disparity in Total Literacy } & \multicolumn{3}{|c|}{ Disparity in Rural Literacy } & \multicolumn{3}{|c|}{ Disparity in Urban Literacy } \\
\hline & 1991 & 2001 & 2011 & 1991 & 2001 & 2011 & 1991 & 2001 & 2011 \\
\hline Zawlnuam & 0.156 & 0.088 & 0.165 & 0.184 & 0.121 & 0.201 & 0.067 & -0.011 & 0.03 \\
\hline West Phaileng & 0.321 & 0.281 & 0.259 & 0.321 & 0.281 & 0.259 & 0 & 0 & 0 \\
\hline Reiek & 0.106 & 0.076 & 0.038 & 0.115 & 0.075 & 0.039 & 0.054 & 0.084 & 0.033 \\
\hline Thingdawl & 0.096 & 0.057 & 0.053 & 0.13 & 0.08 & 0.085 & 0.054 & 0.019 & -0.001 \\
\hline Bilkhawthlir & 0.131 & 0.077 & 0.061 & 0.144 & 0.07 & 0.097 & 0.131 & 0.087 & 0.04 \\
\hline Darlawn & 0.1 & 0.054 & 0.011 & 0.098 & 0.057 & 0.011 & 0.115 & 0.04 & 0.016 \\
\hline Phullen & 0.059 & 0.091 & 0.087 & 0.059 & 0.091 & 0.087 & 0 & 0 & 0 \\
\hline Aibawk & 0.098 & 0.047 & 0.016 & 0.098 & 0.047 & 0.016 & 0 & 0 & 0 \\
\hline Tlangnuam & 0.082 & 0.008 & -0.007 & 0.03 & 0.042 & 0.002 & 0.063 & 0.007 & 0.003 \\
\hline Thingsulthliah & 0.105 & 0.051 & 0.015 & 0.11 & 0.062 & 0.026 & 0.098 & 0.027 & -0.011 \\
\hline Ngopa & 0.119 & 0.125 & 0.088 & 0.119 & 0.125 & 0.088 & 0 & 0 & 0 \\
\hline Khawzawl & 0.126 & 0.043 & 0.054 & 0.141 & 0.105 & 0.064 & 0.1 & -0.048 & 0.033 \\
\hline Champhai & 0.073 & 0.092 & 0.044 & 0.121 & 0.195 & 0.052 & 0.059 & 0.059 & 0.043 \\
\hline Khawbung & 0.174 & 0.146 & 0.053 & 0.174 & 0.146 & 0.053 & 0 & 0 & 0 \\
\hline East Lungdar & 0.092 & 0.038 & 0.021 & 0.091 & 0.046 & 0.025 & 0.1 & 0.016 & 0.015 \\
\hline Serchhip & 0.103 & 0.061 & 0.007 & 0.103 & 0.068 & 0.03 & 0 & 0.057 & -0.009 \\
\hline Bunghmun & 0.279 & 0.243 & 0.228 & 0.279 & 0.243 & 0.228 & 0 & 0 & 0 \\
\hline Lungsen & 0.305 & 0.325 & 0.28 & 0.341 & 0.353 & 0.306 & 0.209 & 0.175 & 0.132 \\
\hline Lunglei & 0.102 & 0.04 & 0.031 & 0.117 & 0.07 & 0.067 & 0.096 & 0.029 & 0.012 \\
\hline Hnahthial & 0.082 & 0.014 & 0.029 & 0.082 & 0.036 & 0.022 & 0 & -0.042 & 0.05 \\
\hline Chawngte & 0.614 & 0.202 & 0.461 & 0.614 & 0.202 & 0.461 & 0 & 0 & 0 \\
\hline Lawngtlai & 0.142 & 0.144 & 0.136 & 0.142 & 0.144 & 0.204 & 0 & 0 & 0.073 \\
\hline Bungtlang $\mathrm{S}$ & 0.381 & 0.344 & 0.296 & 0.381 & 0.344 & 0.296 & 0 & 0 & 0 \\
\hline Sangau & 0.193 & 0.103 & 0.078 & 0.193 & 0.103 & 0.078 & 0 & 0 & 0 \\
\hline Tuipang & 0.184 & 0.19 & 0.13 & 0.184 & 0.19 & 0.13 & 0 & 0 & 0 \\
\hline Saiha & 0.182 & 0.105 & 0.051 & 0.22 & 0.162 & 0.106 & 0.161 & 0.07 & 0.021 \\
\hline Mizoram & 0.132 & 0.086 & 0.084 & 0.164 & 0.135 & 0.145 & 0.084 & 0.022 & 0.015 \\
\hline
\end{tabular}

Source: Computed by the authors from PCA 1991, $2001 \& 2011$

\section{SPATIO- TEMPORAL PATTERN OF GENDER DISPARITIES IN MIZORAM}

The art of reading and writing was introduced to the study area by the Christian Missionaries. They prepared Mizo alphabet 'A, Aw, B' in roman script based on phonetics in 1895. The first modern educational institution began with the opening on one school in 1898, followed by the opening of three schools in the following year. This marked the beginning of universal literacy in Mizoram. When the first census was conducted in Mizoram in 1901, the literacy rate was only $0.98 \%$ which rose to $3.98 \%$ in $1911,81.23 \%$ in 1981 and $88.9 \%$ in 2001. Within a span of just 100 years, by 2011 the literacy rate rose to $91.33 \%$ thereby making Mizoram the third most literate state in India. But the rate of literacy is quite uneven among in Mizoram through time and space.

Table-1 presented the gender disparity index of each Rural Development Blocks in Mizoram for three decadal censuses, i.e. 1991, 2001 and 2011 and its rural urban differential. It can be seen that the gender disparity in literacy for the State was 0.132 in 1991 , 
which declined to 0.086 in 2001 and 0.84 in 2011 . Several factors can be attributed to this decreasing gap between male and female literacy. Government efforts supported by community based organisation, changes in societal views of women status, economic growth etc are instrumental in improving literacy rate in general and female literacy rate in particular. More and more family are in a position to send their daughter to school and the prejudice against women education and their engagement in job outside of home is viewed differently from the early times. The rural-urban differentials in this context also change through time although the urban area fared much better than their rural counterparts. The gender disparity index for rural areas was 0.164 in $1991,0.135$ in 2001 and 0.145 in 2011. Out of the 26 RD Blocks, 23 shows a declining trend in gender disparity in literary; and 3 RD Blocks namely Chawngte, Zawlnuam and Thingdawl recorded an increasing gap in male female literacy during 2001-2011. For urban areas, the disparity index was negligible and it was as low as 0.84 in 1991 which declined to 0.022 in 2001 and 0.015 in 2011. Three RD Blocks namely Thingdawl, Tlangnuam and Serchhip even shows a reverse gender gap i.e. female literacy rate is higher than male literacy rate.

Table.2- Block Level Disparity Region in Literacy 1991-2011

\begin{tabular}{|c|c|c|c|c|c|c|}
\hline \multirow[b]{2}{*}{ Value of DI } & \multicolumn{2}{|l|}{1991} & \multicolumn{2}{|l|}{2001} & \multicolumn{2}{|l|}{2011} \\
\hline & Name of Block & $\begin{array}{l}\text { No. of } \\
\text { Block } \\
\text { S }\end{array}$ & Name of Block & $\begin{array}{l}\text { No. of } \\
\text { Blocks }\end{array}$ & Name of Block & $\begin{array}{l}\text { No. of } \\
\text { Blocks }\end{array}$ \\
\hline $\begin{array}{l}<0.10 \\
(\text { Low })\end{array}$ & $\begin{array}{l}\text { Phullen, Champhai, } \\
\text { Tlangnuam, Hnahthial, } \\
\text { East Lungdar, } \\
\text { Thingdawl, Aibawk, } \\
\text { Darlawn }\end{array}$ & 8 & $\begin{array}{l}\text { Tlangnuam Hnahthial, } \\
\text { East Lungdar, Lunglei, } \\
\text { Khawzawl, Aibawk, } \\
\text { Thingsulthliah, } \\
\text { Darlawn, Thingdawl, } \\
\text { Serchhip, Reiek, } \\
\text { Bilkhawthlir, } \\
\text { Zawlnuam, Phullen, } \\
\text { Champhai }\end{array}$ & 15 & $\begin{array}{l}\text { Tlangnuam, Serchhip, } \\
\text { Darlawn, } \\
\text { Thingsulthliah, Aibawk, } \\
\text { East Lungdar, } \\
\text { Hnahthial, Lunglei } \\
\text { Reiek, Champhai, } \\
\text { Saiha, Thingdawl, } \\
\text { Khawbung, Khawzawl, } \\
\text { Bilkhawthlir, Sangau, } \\
\text { Phullen, Ngopa }\end{array}$ & 18 \\
\hline $\begin{array}{c}1.01-2.00 \\
\text { (Medium) }\end{array}$ & $\begin{array}{l}\text { Lunglei, Serchhip, } \\
\text { Thingsulthliah, Reiek, } \\
\text { Ngopa, Khawzawl, } \\
\text { Bilkhawthlir, } \\
\text { Lawngtlai, Zawlnuam, } \\
\text { Khawbung, Saiha, } \\
\text { Tuipang, Sangau }\end{array}$ & 13 & $\begin{array}{l}\text { Sangau, Saiha, Ngopa, } \\
\text { Lawngtlai, Khawbung, } \\
\text { Tuipang }\end{array}$ & 6 & $\begin{array}{l}\text { Tuipang, Lawngtlai, } \\
\text { Zawlnuam }\end{array}$ & 3 \\
\hline $\begin{array}{c}\text { 2.01-3.00 } \\
\text { (High) }\end{array}$ & Bunghmun & 1 & $\begin{array}{l}\text { Chawngte, } \\
\text { Bunghmun, West } \\
\text { Phaileng }\end{array}$ & 3 & $\begin{array}{l}\text { Bunghmun, West } \\
\text { Phaieng, Lungsen, } \\
\text { Bungtlamg S }\end{array}$ & 3 \\
\hline $\begin{array}{l}>3.00 \\
\text { (Very High) }\end{array}$ & $\begin{array}{l}\text { Lungsen, West } \\
\text { Phaileng, Bungtlang S, } \\
\text { Chawngte }\end{array}$ & 4 & Lungsen, Bungtlang S & 2 & Chawngte & 1 \\
\hline
\end{tabular}

Based on the disparity index, the 26 Blocks have been divided into four regions (Table-2) - Low disparity, Medium disparity, High disparity and Very high disparity region:. 


\section{Low Disparity Region $(<0.10)$ :}

There are 18 RD Blocks that fall under this category in 2011, covering about $2 / 3^{\text {rd }}$ of the entire region. The numbers of blocks that can be classed in this category increase from just 8 in 1991 to 15 in 2001.This declining pattern of gender disparity in literacy represent improvement of women status in the region. The North and Eastern part performed much better than the South and Western part of the State. Tlangnuam Block which is also the location of the State capital Aizawl has the distinction of being the only RD Block recording reverse gender gap. RD Blocks that are located near Aizawl city such as Thingdawl, Aibawk, Reiek Thingsulthliah also experienced declining gender gap. The effort taken up by the State Government during the 1990's, greatly supported by local bodies, NGO and Churches to identify illiterates and teach them how to read and write paid off and the result was observed in these region.

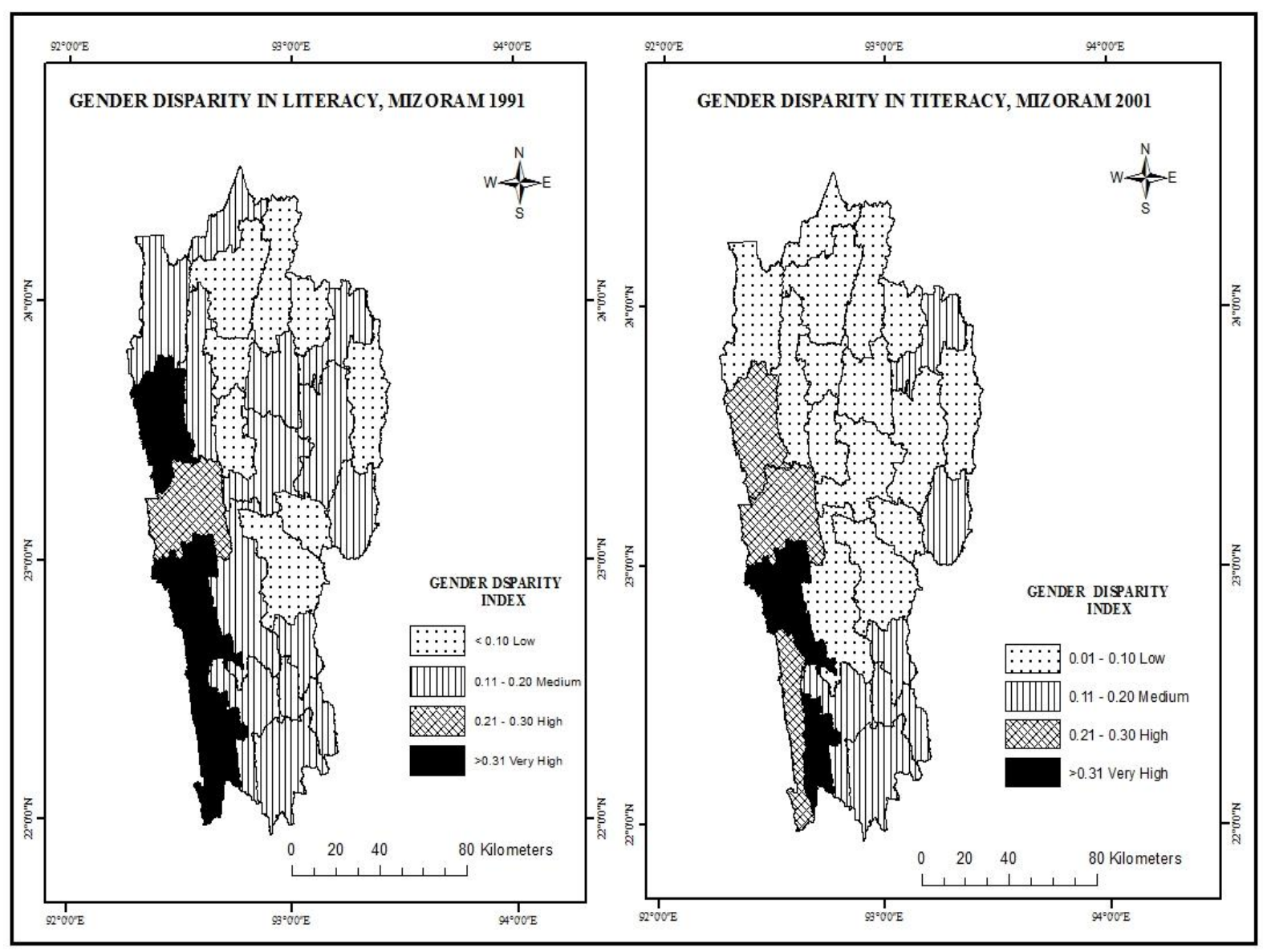

Fig.2- Spatial Pattern of Gender Disparity in Literacy, 1991

Fig.3- Spatial Pattern of Gender Disparity in Literacy, 2001

\section{Medium Disparity Region (0.11-0.20):}

Tuipang, Lawngtlai and Zawlnuam are included in this category in 2011, while in 1991 there are 13 Blocks and 6 in 2001 that can be classed as medium disparity region. Tuipang and Lawngtlai Blocks are located in the southern end of the State and Zawlnuam Block is located in the northwest bordering Tripura. These 3 Blocks have higher percentage of migratory tribes like Bru and Chakma and their communities are traditionally less aware towards education. The decline of disparity index in Zawlnuam in 2001 and the increase in disparity in 2011 is mainly due to the displacement of Brus to Tripura in the late 1990's and their subsequent repatriation in the 2000 's.

\section{High Disparity Region (0.21-0.30):}

In 1991, there is only 1 RD Block i.e. Bunghmun, that falls under this category, but the number increase to 3 in 2001 and 4 in 2011. Bunghmun, West Phaileng, Lungsen and Bungtlang S are the blocks with high gender gap in 2011. All tese blocks are located in the western part of the State along Indo- Bangladesh border. They consist of 100\% rural population, and many villages in these blocks are not yet connected with metalled road. High concentration of two tribal communities Riang and Chakma, that are more primitive and migratory in nature is one of the main cause of gender disparity. Due to their frequent shifting from one place to another, it is hard to send their children, especially female to school. Their frequent movement is mainly motivated by availability of jhum land and that 
also in small batches makes it harder for them to have access to educational institution as it is impossible for the government to open school in every place they move. Moreover, due to poverty and lack of awareness many families prefer to send their child instead of sending them to school.

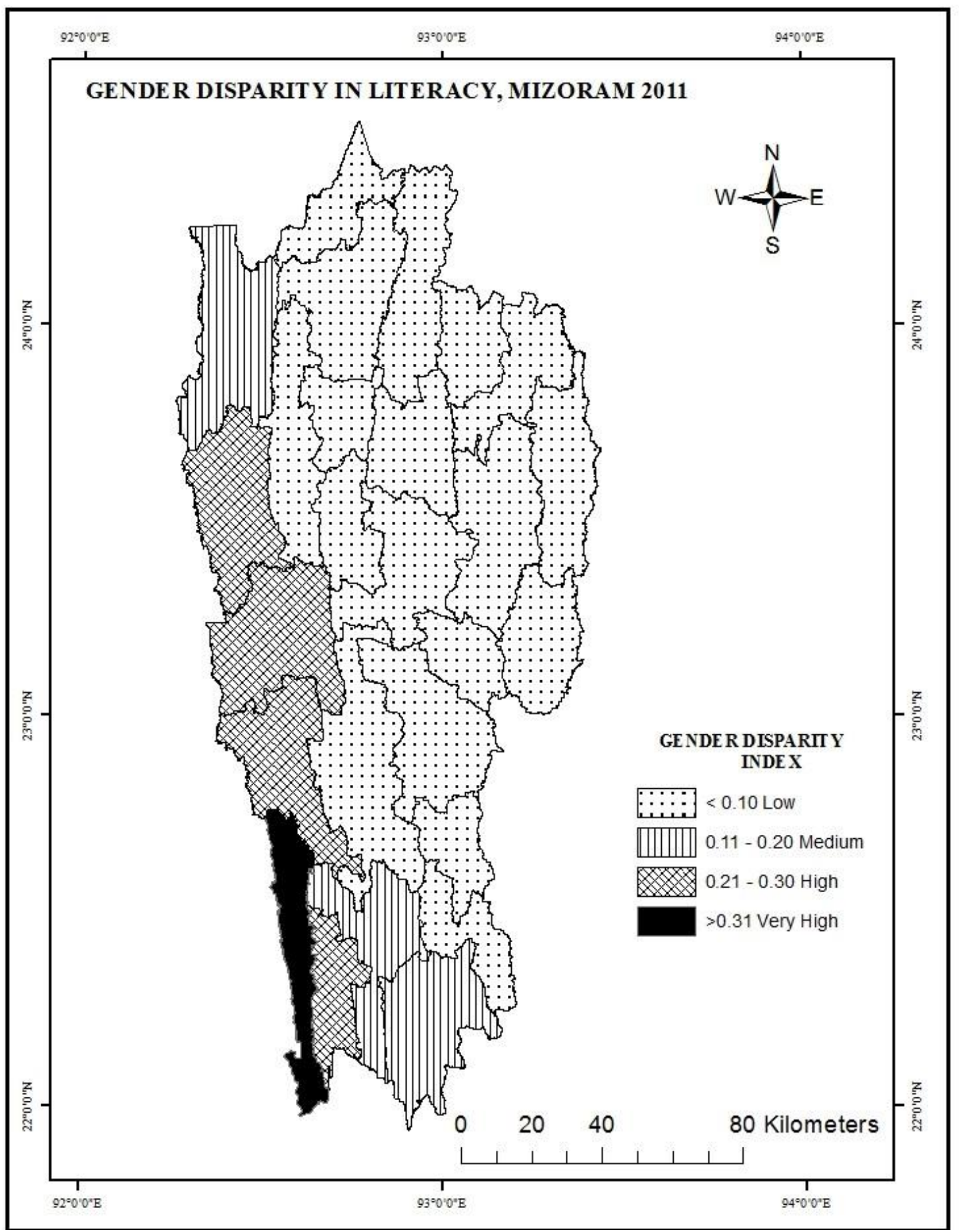

Fig.4- Spatial Pattern of Gender Disparity in Literacy, 2011

\section{Very High Disparity Region (> 0.31):}

One RD Block Chawngte with a disparity index of 0.461 is the only block that can be classed under this category in 2011. In 1991, there were 4 RD Blocks in this category which decrease to 2 blocks in 2001. Chawngte Block is located in the south western 
part of the State along Indo-Bangladesh border. It is falls under the Chakma Autonomous District Council and the majority of the population consist of Chakma tribe. As it is located along the Indo- Bangladesh border, the region experienced an influx of illegal i migrants from Bangladesh since long which is one important reason of low literacy. Poverty, distance from the centre, ignorance, bad connectivity in terms of transportation as well as communication all add to the unceasing low literacy and the wide gender gap in literacy.

\section{CONCLUSION}

VI.

The empirical analysis presented in the above discussion clearly shows that although the degree of literacy rate in Mizoram is high as compared to many Indian States, disparity between male and female is also present unevenly. This disparity is even more evident in rural areas than in urban areas. The western and southern part of the State, lying along the international border displays higher disparity index than the north and east. Economically backward and predominantly agricultural society in rural areas is more prone to ignorance and they are acutely unaware of the importance of education. In addition, the impact of Christianity is still obvious long after the missionaries are gone because the Church continues to impart education to their members. This is one important reason why the Mizos, the predominant tribal group in Mizoram, who are Christian have very high literacy rate. On the other hand, the concentration of other tribal communities like Reang and Chakma who follows Hinduism and Buddhism shows higher gender disparity in literacy and overall low literacy rate. It is imperative for the government and other agencies to make suitable plan to bring the gap in literacy rate. High growth rate of population in economically backward area, coupling with increasing gap between food supply and demand is a matter of concern. Development of road transportation, which is the only means of transportation in most part of Mizoram, is required to reach people living in the remote corner and bring them out of their ignorance.

\section{References}

1. Census of India (1991): Primary Census Abstract, Mizoram

2. Census of India (2001): Primary Census Abstract, Mizoram

3. Census of India (2011): Primary Census Abstract, Mizoram

4. Chandna, R.C (2000): Geography of Population: Concept, Determinants and Patterns, Kalyani Publishers, New Delhi

5. Choubey, Alok Kumar and Gayatri Rai (2019): 'Gender Disparity in Literacy and Its Rural-Urban Differentials: Block Wise Evidences from Lucknow District, UP' National Geographic Journal of India, Vol.65 No.1

6. De, Jaydip (2015): 'Gender Disparity in Literacy: A Macro Level Spatio-Temporal Account of India', Journal of Humanities and Social Science, Vol.20, Issue 10, pp 52-59

7. Mohapatra, A.C (1993): 'Determinants of Regional Disparities in Level of Literacy in North East India: Planning Strategies for Removal of Disparities in Regional Disparites' in Educational Development edited by S.C. Nuna, South Asian Publisher, New Delhi pp 258-494.

8. Nayak, L.T (2011): 'Gender Disparities in the Levels of Literacy Rate in Karnataka: A District Level Analysis' Geographical Review of India, 73(3) pp 239-256

9. Pachuau, Rintluanga (2009): Mizoram: A Study in Comprehensive Geography, Northern Book Centre, New Delhi

\section{AUTHORS}

First Author -Janet Laltlansangi, Assiatant Professor, Department of Geography, Governmentt Kolasib College, Mizoram Email: klb.janet@gmail.com

Second Author - C. Laldingliana Assiatant Professor, Department of Geography, Lunglei Government College, Mizoram Email: puipuiipachawngthu@gmail.com

Third Author - Jacinta Vanlalrinzuali, Assiatant Professor, Department of Geography, Lunglei Government College, Mizoram Email: jacintavlrz@gmail.com

Correspondence Author - Janet Laltlansangi , Email: klb.janet@gmail.com, janet.hmaryahoo.com Contact No: (91) 9862233796 